Original Research Paper

\title{
Group Decision Support System to Determine Regional Development Priority Using the Item-Based Clustering Hybrid Method
}

\author{
${ }^{1}$ Sri Setiyowati, ${ }^{2}$ Sumiati, ${ }^{3}$ Sutarti, \\ ${ }^{4}$ Andrianto Heri Wibowo, ${ }^{2}$ Vidila Rosalina and ${ }^{2}$ Tb. Ai Munandar \\ ${ }^{I}$ Department of Informatics Management, \\ Faculty of Computer Science and Informatics, Univ. Mathla'ul Anwar, Banten, Indonesia \\ ${ }^{2}$ Department of Informatics Engineering, \\ Faculty of Information Technology, Universitas Serang Raya, Banten, Indonesia \\ ${ }^{3}$ Department of Computer Engineering, \\ Faculty of Information Technology, Universitas Serang Raya, Banten, Indonesia \\ ${ }^{4}$ Department of Information Systems, \\ Faculty of Comp. Science and Informatics, Universitas Mathla'ul Anwar, Banten, Indonesia
}

Article history

Received: 18-09-2018

Revised: 28-12-2018

Accepted: 18-04-2019

Corresponding Author:

Tb. Ai Munandar

Department of Informatics

Engineering, Faculty of

Information Technology,

Universitas Serang Raya,

Banten, Indonesia

Email: tbaimunandar@gmail.com

\begin{abstract}
Determination of regional development priorities is usually influenced by two factors, firstly the policy-making subjectivity (regional head) second to the results of the development data analysis. But both often do not go hand in hand because in fact subjectivity is more dominant than combining the two. The development of computational technology, especially in the area of decision support, provides space to solve various problems related to the decision making process. This study aims to develop a Group Decision Support System (GDSS) model for determining regional development priorities in the future. An alternative approach in the form of developing a GDSS model is carried out so that it can be used to determine regional development priorities that are able to combine analysis of data on development results and subjectivity of policy makers. It means, policy-enforcing subjectivity still exists but the results of development data analysis are also used. This model combines the GDSS concept, MVHAC cluster technique and Item-based Cluster Hybrid Method (ICHM) to accommodate joint decision making from each group decision maker. The results of the testing of the model developed against six regions in Banten Province show that there are three regions that must be prioritized in the future. Those are Pandeglang, Lebak and Kota Serang.
\end{abstract}

Keywords: Decision Support System Group, MVHAC, ICHM, Decision Maker Group, Regional Development Priorities

\section{Introduction}

Regional development theory is inseparable from the concept of economic development gap in a region (Munandar et al., 2016). There are many measuring instruments commonly used to identify development gaps such as the Klassen typology (Hariyanti and Utha, 2016; Suwandi, 2015; Endaryanto et al., 2015; Fattah and Rahman, 2013; Karsinah et al., 2016) and Location Quotient (Sinaga, 2015; Bakaric, 2005). The results of the analysis of these two approaches are usually used to determine development priorities in the future.
Sometimes, the use of Klassen and Location Quotient (LQ) is able to avoid the policy subjectivity. But on the other hand the results of analysis of development data with tools such as Klassen and LQ often contradict reality. Many statistical data that display the results of development is very good from an area, in fact it actually happens quite the opposite. Therefore, subjectivity is also an important part of determining the direction of regional development priorities. Subjective judgments often arise because they see first hand the facts that occur and there is nothing wrong with that. 
The main problem that often occurs in government is the inability to balance the subjectivity and results of development data analysis, especially in efforts to determine the priority of the area to be built. Often the subjectivity is more instrumental in determining the priority of the region so that aside from the existing development achievement data, so too sometimes the opposite. Therefore, it's needed the special approach that is able to accommodate subjective assessment and the results of development data analysis so that policy makers can prioritize areas to be built as fairly as possible.

These research is undertaken essentially concerns development of a model that can be used as an alternative approach, especially in determination of areas which should get priority in the future development process. This model is also able to combine subjective assessment of each policy maker with data on development achievement of an area prior to determination of areas which should take priority. In the model developed, the concept of the Group Decision Support System (GDSS) is the main approach. Based on the latest literature study conducted, the GDSS and ICHM approach has not been used for the process of determining regional development priorities. Particularly combining the assessment of expert, community, academic components with regional development statistics.

GDSS is comprised of four primary components, namely people, hardware, software and procedure (Zhao et al., 2017). The model developed in this research focuses on modification of two constituent components of GDSS, namely people and procedure. For the component people, each decision maker (member) was grouped into a particular Group Decision Maker (GDM) by his/her characteristics. Each GDM member certainly has different assessment of the development achievement based on the reality she/he have seen. As for the component procedure, ranking and selection of alternatives is commonly undertaken using the approach Multi-Attribute Decision Making (MADM). The approach Item-based Clustering Hybrid Method (ICHM) was employed at the stage of final ranking to combine subjective assessment of GDMs and the data on development achievement of a region.

\section{Group Decision Support Systems (GDSS)}

GDSS is a computer-based tool that is used to help determine selected alternatives from several alternatives available through the decision-making process by a group of people working together. In the GDSS concept everyone involved in alternative action actions exchanges ideas, opinions and preferences between one group member and another member to produce a series of joint decisions (Zhao et al., 2017; Instudor and Duta, 2010). Joint decision making certainly may involve a great number of decision makers and alternatives that are not only a few as well (Morente-Molinera et al., 2018) and, moreover, GDSS can also use incomplete information for decision making (Capuano et al., 2018; Lan et al., 2013). Currently, the concepts of group decision support have developed rapidly. In addition to its ability to be applied to various business domains, group decision support can also be used as the right tool to optimize the decisions generated (Rigopoulos, 2015). Many studies use GDSS to find an answer to cases such as distribution of information about the battlefield and a fast and accurate decision-making process in the military sector (Lee and Zo, 2016), management of emergency security systems (Chen et al., 2018), logistics (Silva Filho and Morais, 2018) and how to bring together experts and certain disciplines so as to establish a policy that can be accepted by everyone (Nikas et al., 2018). In general, GDSS is comprised of four main components, namely:

1. Hardware, which refers to tools prepared to facilitate group decision makers (GDM) to work together making a decision. Several tools used may include a special room for decision making, a set of computers, internet access and other communication devices

2. Software, which refers to tools prepared to help decision makers analyze input data so as to generate a number of decisions. Software that is commonly used includes e-questionnaires, ebrainstorming, group dictionaries and questionnaire and policy information tools

3. People, which refer to a group of people undertaking activities to generate a set of decisions. For example, decision makers, facilitator or staff authorized to make decisions

4. Procedures, which refer to methods adopted to analyze input data by the component people so as to generate a set of expected decisions

\section{Item-Based Clustering Hybrid Method (ICHM)}

ICHM is an approach that is usually used to provide recommendations for certain product items sold online. Provision of recommendations is based on new items that exist and have not been rated by the user (Djamal et al., 2010). The recommendations given are usually the best offer from a product preferred the most by others (Laksana, 2014).

ICHM is a combination of collaborative filtering and content-based filtering. Both methods have their own weaknesses, which are inability to recommend an item that has not been rated by users and an item with a content that is different from the content of the previously selected item (Laksana, 2014; Li and Kim, 2003). The following are the stages to determine recommendations using ICHM (Li and Kim, 2003): 
1. Implement a clustering algorithm to the content of an item. Clustering algorithms are used at this stage to determine several data groups. Afterwards, create a group-rating matrix by calculating the probability of each item to be classified to each cluster using the following equation:

$$
\operatorname{Pro}(j, k)=1-\frac{C S(j, k)}{\max C S(j, k)}
$$

where, $\operatorname{Pro}(j, k)$ is probability of item $j$ to be part of cluster $k . C S(j, k)$ is counter-similarity between item $j$ and cluster $k$. Calculated using Euclidian Distance. $\max C S(i, k)$ is the highest similarity value of item $i$ and cluster $k$

2. Calculate similarity for group-rating and itemrating matrices. The group-rating similarity is calculated using adjusted cosine similarity, while item-rating similarity is calculated using Pearson correlation-based similarity. The following are the two equations:

a. Pearson correlation-based similarity:

$$
\operatorname{sim}(k, l)=\frac{\sum_{u=1}^{m}\left(R_{u, k}-\overline{R_{k}}\right)\left(R_{u, l}-\overline{R_{l}}\right)}{\sqrt{\sum_{u=1}^{m}\left(R_{u, k}-\overline{R_{k}}\right)^{2}} \sqrt{\sum_{u=1}^{m}\left(R_{u, l}-\overline{R_{l}}\right)^{2}}}
$$

where, $\operatorname{sim}(k, l)$ is the similarity value of item $k$ and item $l, m$ is total number of users rating item $k$ and item $l, \overline{R_{k}}$ and $\overline{R_{l}}$ is average rating of item $k$ and item $l, R_{u, k}$ and $R_{u, l}$ is rating from user $u$ for item $k$ and item $l$

b. Adjusted cosine similarity:

$$
\operatorname{sim}(k, l)=\frac{\sum_{u=1}^{m}\left(R_{u, k}-\overline{R_{u}}\right)\left(R_{u, l}-\overline{R_{u}}\right)}{\sqrt{\sum_{u=1}^{m}\left(R_{u, k}-\overline{R_{u}}\right)^{2}} \sqrt{\sum_{u=1}^{m}\left(R_{u, l}-\overline{R_{u}}\right)^{2}}}
$$

where, $\operatorname{sim}(k, l)$ is the similarity value of item $k$ and item $l . m$ is total number of users rating item $k$ and item $l . \overline{R_{u}}$ is average rating of user $u$ and $R_{u, k}$ and $R_{u, l}$ is rating from user $u$ for item $k$ and item $l$

3. Results of similarity calculation for the grouprating and item-rating matrices are then combined using the following combination of ICHM:

$$
\begin{aligned}
& \operatorname{sim}(k, l)=\operatorname{sim}(k, l)_{\text {item }} \times(1-c) \\
& +\operatorname{sim}(k, l)_{\text {group }} \times c
\end{aligned}
$$

where, $\operatorname{sim}(k, l)$ is similarity value of item $k$ and item $l$. $c$ is combined coefficient ranging from $0-1$. $\operatorname{sim}(k, l)_{\text {item }}$ is similarity for item $k$ and item $l$ obtained from item-rating similarity calculation. $\operatorname{sim}(k, l)_{\text {group }}$ is similarity for item $k$ and item $l$ obtained from group-rating similarity calculation.

4. Calculate the prediction of an item. The prediction is calculated using two approaches, namely items that have been rated by other users (non cold-start problem) and items that have never been rated at all (cold-start problem).

a. Non cold-start problem, the following is the equation used:

$$
P_{u, k}=\overline{R_{k}}+\frac{\sum_{i=1}^{n}\left(R_{u, i}-\overline{R_{i}}\right) x \operatorname{sim}(k, i)}{\sum_{i=1}^{n}|\operatorname{sim}(k, i)|}
$$

where, $P_{u, k}$ is predicted rating of item $k$ for user $u$. $n$ is number of rated items of user $u$. $R_{u, i}$ is rating from user $u$ for item $i . \overline{R_{k}}$ and $\overline{R_{l}}$ is average rating for item $\mathrm{k}$ and item i. $\operatorname{sim}(\mathrm{k}, \mathrm{i})$ is similarity value of item $k$ and the whole rated items of active users.

b. Cold-start problem, the following is the equation used:

$$
P_{u, k}=\overline{R_{k}}+\frac{\sum_{i=1}^{n} R_{u, i} x \operatorname{sim}(k, i)}{\sum_{i=1}^{n}|\operatorname{sim}(k, i)|}
$$

where, $P_{u, k}$ is predicted rating of item k for user $u, n$ is number of rated items of user $\mathrm{u}, R_{u, i}$ is rating from user $u$ for item $i$ and $\operatorname{sim}(k, i)$ is similarity value of item $\mathrm{k}$ and the $i^{\text {th }}$ rated item.

\section{Research Methodology}

This research begins with a literature study and analyzes a number of data related to the process of identifying regional inequality and determining development priorities based on the results of several previous studies. The next step is to design a group decision support systems model. Data collection was conducted in two stages, first collecting secondary data from the Banten Province Statistics Center, secondly distributing online questionnaires to each member of Group Decision Maker (GDM) to conduct regional development assessments that were the object of research based on real facts in the field. The results are included into the model to determine regional development priorities in the future. The final output of the model will be compared with the results of the analysis of prioritizing regional development using Klassen. This study uses data on the sector of Gross Regional Domestic Income (GRDP) of six districts in Banten Province. The six districts are Pandeglang, Tangerang, Lebak, Kota, Tangerang, Cilegon and Serang. 


\section{Proposed Model: GDSS based ICHM}

The GDSS model developed consists of several main stages. The first is the assessment of the alternatives by each member of the Group Decision Maker (GDM) on the development results based on facts. Second, the process of clustering data on development results obtained based on data collection from the Central Statistics Agency. Third, combining the results of the first and second stages then processed using the itembased cluster hybrid method (ICHM). The fourth stage is a ranking process which is followed by the selection of regional alternatives for future development priorities. The GDSS model is generally as shown in Fig. 1.

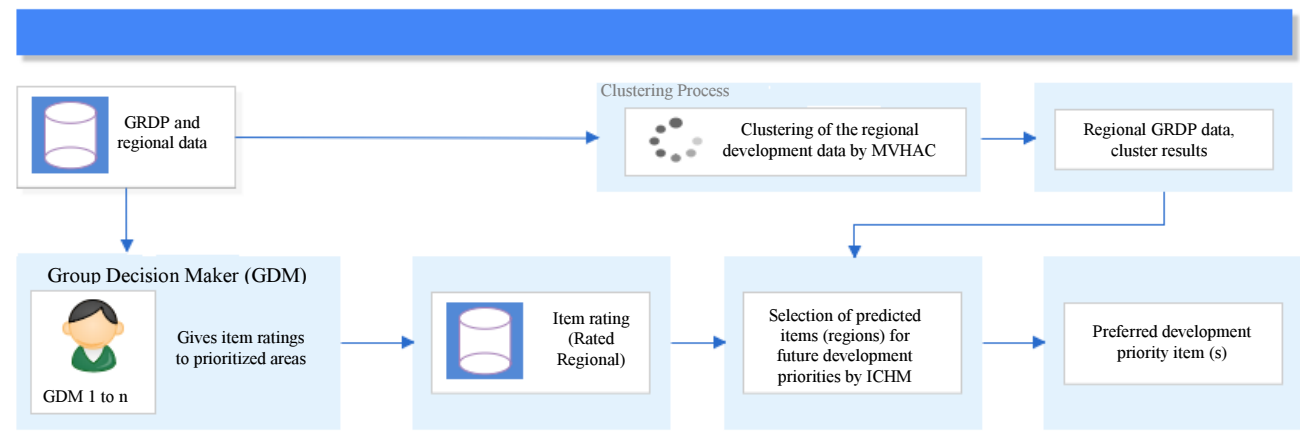

Fig. 1: Stages of the GDSS model

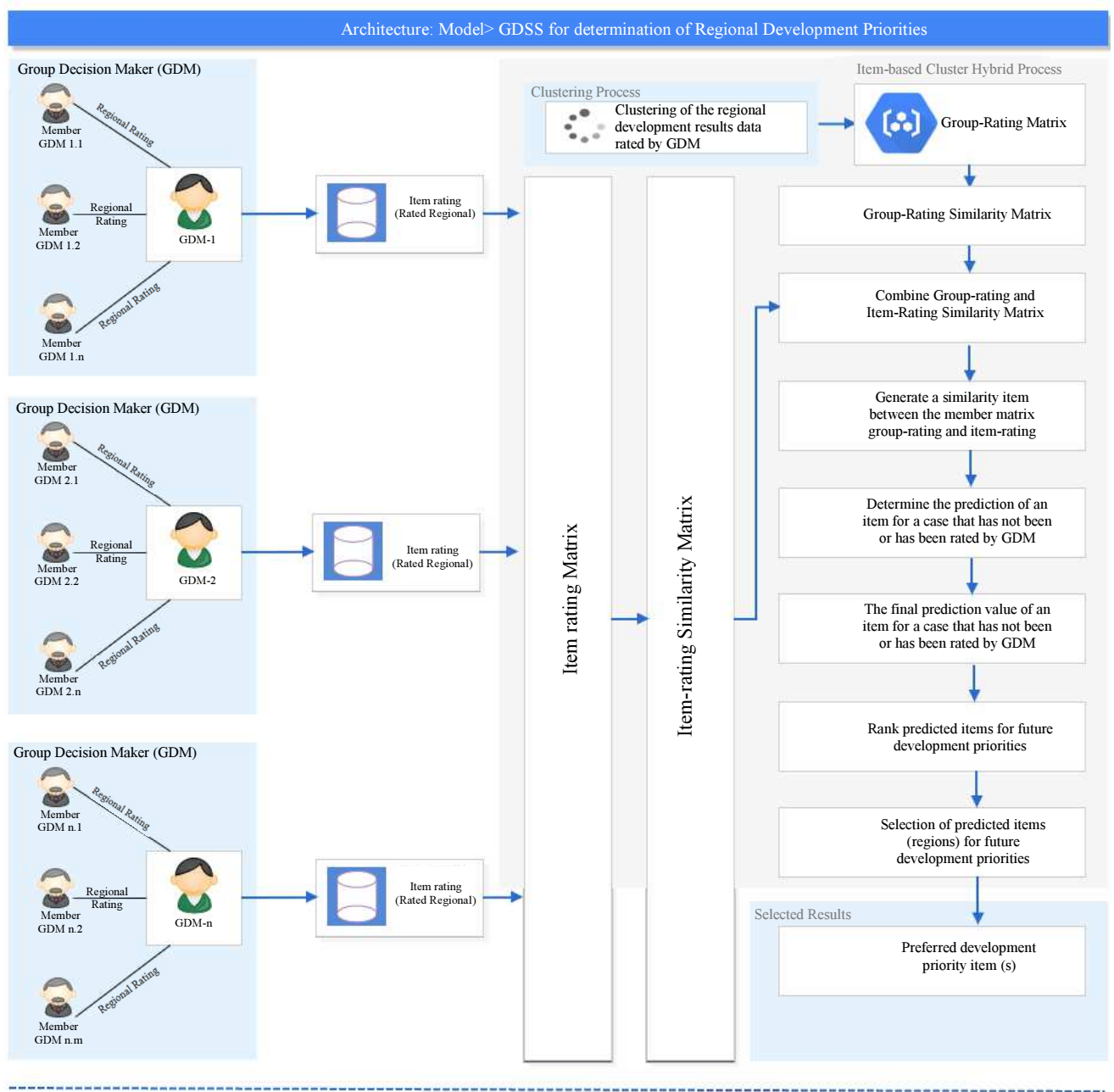

Fig. 2: Description of the GDSS model 
In the first stage, the assessment of the priority areas of each GDM is presented in the form of a questionnaire in which each GDM member is asked to choose a region which he thinks must be prioritized in future development activities. Fill in the questionnaire value based on the four categories of development inequality according to Klassen's typology. Therefore, every member of GDM only needs to choose one of the values which is the closest to be chosen as a priority of the area that must be built. In the second stage, clustering techniques are used to form cluster groups of items (regions) that will be ranked in the next stage. Generally ICHM uses the k-means technique to form a cluster group of items that will be recommended, but in this model a Multi-View Hierarchical Agglomerative Clustering (MVHAC) technique is used. The third stage is to combine the first phase with the second stage. At this stage the results of the assessment of GDM and cluster data were analyzed using the ICHM approach. The fourth stage is the final stage where the results of calculations with ICHM are ranked and selected alternatives (regions) that will be prioritized in future development activities. The GDSS model is more detailed as shown in Fig. 2.

\section{Result and Discussion}

The rating item (region) process in this study displays an assessment questionnaire on the GDSS.
Each member of the Group Decision Maker (GDM) gives a rating on the area that must be prioritized in the next development activity. The rating scale is taken from four regional development gap categories based on Klassen's typology analysis. The rating range is determined between 1-4. The higher of the range of values chosen by GDM members, the higher the priority of a region to be prioritized.

In this study there are three types of GDM that provide rating ratings on priority areas. Those are the (government) policy [GMD-1] policy groups, academics [GDM-2] and the general public (including NonGovernmental Organizations) [GDM-3]. The results of the rating of the three GDM groups show that there are 24 GDM members who give ratings on areas that they think are worthy of priority. Table 1 shows the results of rating given by each GDM member.

The GDM rating result will be used as a matrix rating item to then calculate its similarity item rating. The next step is to group the development outcome data for the region which is also rated by GDM. In this study, groupings used the MHVAC cluster technique and were clustered into two large groups. The cluster results are then used as a group-rating to then calculate the similarity group rating. Table 2 and 3 show the similarity item-rating and similarity group-rating respectively.

Table 1: Rating to determine development priority by region by GDMs

\begin{tabular}{|c|c|c|c|c|c|c|c|}
\hline \multirow[b]{2}{*}{ Group DM } & \multirow[b]{2}{*}{$\begin{array}{l}\text { Member } \\
\text { of GDM }\end{array}$} & \multicolumn{6}{|l|}{ Disctrict } \\
\hline & & $\begin{array}{l}\text { Kab. } \\
\text { Pandeglang }\end{array}$ & $\begin{array}{l}\text { Kab. } \\
\text { Tangerang }\end{array}$ & $\begin{array}{l}\text { Kab. } \\
\text { Lebak }\end{array}$ & $\begin{array}{l}\text { Kota } \\
\text { Cilegon }\end{array}$ & $\begin{array}{l}\text { Kota } \\
\text { Serang }\end{array}$ & $\begin{array}{l}\text { Kota } \\
\text { Tangeran }\end{array}$ \\
\hline GDM-1 & GDM-1.1 & 4 & 1 & 4 & 3 & 1 & 1 \\
\hline (policy maker/ & GDM-1.2 & 4 & 1 & 4 & 1 & 2 & 1 \\
\hline government institution) & GDM-1.3 & 4 & 1 & 3 & 1 & 2 & 1 \\
\hline GDM-2 & GDM-2.1 & 3 & 2 & 3 & 2 & 2 & 1 \\
\hline \multirow[t]{16}{*}{ (Academician) } & GDM-2.2 & 3 & 1 & 2 & 1 & 1 & 1 \\
\hline & GDM-2.3 & 3 & 2 & 3 & 2 & 2 & 1 \\
\hline & GDM-2.4 & 3 & 2 & 4 & 1 & 2 & 1 \\
\hline & GDM-2.5 & 2 & 3 & 2 & 2 & 2 & 3 \\
\hline & GDM-2.6 & 3 & 1 & 3 & 1 & 3 & 1 \\
\hline & GDM-2.7 & 2 & 2 & 3 & 2 & 2 & 1 \\
\hline & GDM-2.8 & 2 & 2 & 2 & 2 & 2 & 1 \\
\hline & GDM-2.9 & 3 & 3 & 4 & 3 & 3 & 2 \\
\hline & GDM-2.10 & 4 & 1 & 4 & 3 & 3 & 1 \\
\hline & GDM-2.11 & 3 & 1 & 3 & 1 & 1 & 1 \\
\hline & GDM-2.12 & 3 & 4 & 3 & 4 & 2 & 1 \\
\hline & GDM-2.13 & 3 & 2 & 4 & 1 & 2 & 1 \\
\hline & GDM-2.14 & 3 & 1 & 4 & 2 & 3 & 1 \\
\hline & GDM-2.15 & 3 & 2 & 1 & 2 & 1 & 3 \\
\hline & GDM-2.16 & 4 & 4 & 4 & 4 & 4 & 4 \\
\hline & GDM-2.17 & 4 & 2 & 4 & 1 & 1 & 1 \\
\hline GDM-3 & GDM-3.1 & 3 & 2 & 3 & 2 & 3 & 2 \\
\hline Community (non- & GDM-3.2 & 4 & 1 & 4 & 2 & 3 & 1 \\
\hline governmental & GDM-3.3 & 3 & 3 & 1 & 1 & 2 & 1 \\
\hline organizations) & GDM-3.4 & 4 & 1 & 3 & 1 & 2 & 1 \\
\hline Average & & 3,21 & 1,88 & 3,13 & 1,88 & 2,13 & 1,38 \\
\hline
\end{tabular}


Table 2: Item-rating similarity

\begin{tabular}{lllllll}
\hline Regional & Pandeglang & Kab. Tangerang & Kab. Lebak & Kota Cilegon & Kota Serang & Kota Tangerang \\
\hline Pandeglang & 1 & $-0,305$ & 0,515 & 0,044 & 0,114 & $-0,070$ \\
Kab. Tangerang & $-0,305$ & 1 & $-0,176$ & 0,564 & 0,252 & 0,564 \\
Kab. Lebak & 0,515 & $-0,176$ & 1 & 0,212 & 0,381 & $-0,174$ \\
Kota Cilegon & 0,044 & 0,564 & 0,212 & 1 & 0,425 & 0,453 \\
Kota Serang & 0,114 & 0,252 & 0,381 & 0,425 & 1 & 0,322 \\
Kota Tangerang & $-0,070$ & 0,564 & $-0,174$ & 0,453 & 0,322 & 1 \\
\hline
\end{tabular}

Table 3: Group-rating similarity

\begin{tabular}{lllllll}
\hline Nama Wilayah & Pandeglang & Kab. Tangerang & Kab. Lebak & Kota Cilegon & Kota Serang & Kota Tangerang \\
\hline Pandeglang & 1 & $-0,521$ & 0,999 & 0,667 & 0,999 & $-0,545$ \\
Kab. Tangerang & $-0,521$ & 1 & $-0,552$ & $-0,983$ & $-0,552$ & $-0,432$ \\
Kab. Lebak & 0,999 & $-0,552$ & 1 & 0,695 & 0,695 & $-0,514$ \\
Kota Cilegon & 0,667 & $-0,983$ & 0,695 & 1 & 0,695 & $-0,974$ \\
Kota Serang & 0,999 & $-0,552$ & 0,695 & 0,695 & 1 & $-0,514$ \\
Kota Tangerang & $-0,545$ & $-0,432$ & $-0,514$ & $-0,974$ & $-0,514$ & 1 \\
\hline
\end{tabular}

Table 4: Predictive values of items (Regions)

\begin{tabular}{|c|c|c|c|c|c|c|c|}
\hline \multirow[b]{2}{*}{ Group DM } & \multirow[b]{2}{*}{$\begin{array}{l}\text { Member } \\
\text { of GDM }\end{array}$} & \multicolumn{6}{|l|}{ Disctrict } \\
\hline & & $\begin{array}{l}\text { Kab. } \\
\text { Pandeglang }\end{array}$ & $\begin{array}{l}\text { Kab. } \\
\text { Tangerang }\end{array}$ & $\begin{array}{l}\text { Kab. } \\
\text { Lebak }\end{array}$ & $\begin{array}{l}\text { Kota } \\
\text { Cilegon } \\
\end{array}$ & $\begin{array}{l}\text { Kota } \\
\text { Serang }\end{array}$ & $\begin{array}{l}\text { Kota } \\
\text { Tangerang }\end{array}$ \\
\hline GDM-1 & GDM-1.1 & 3,7 & 1,1 & 3,7 & 2,4 & 2,3 & 0,8 \\
\hline (policy maker/ & GDM-1.2 & 3,7 & 1,1 & 3,6 & 1,8 & 2,2 & 0,9 \\
\hline government institution) & GDM-1.3 & 3,5 & 1,3 & 3,3 & 1,6 & 2,0 & 1,1 \\
\hline GDM-2 & GDM-2.1 & 3,1 & 2,0 & 3,1 & 1,9 & 2,0 & 1,2 \\
\hline \multirow[t]{16}{*}{ (Academician) } & GDM-2.2 & 2,8 & 1,7 & 2,6 & 1,1 & 1,3 & 1,4 \\
\hline & GDM-2.3 & 3,1 & 2,0 & 3,1 & 1,9 & 2,0 & 1,2 \\
\hline & GDM-2.4 & 3,3 & 1,8 & 3,2 & 1,6 & 2,0 & 1,1 \\
\hline & GDM-2.5 & 2,3 & 3,0 & 2,2 & 1,5 & 1,6 & 2,7 \\
\hline & GDM-2.6 & 3,3 & 1,5 & 3,2 & 1,7 & 2,2 & 1,2 \\
\hline & GDM-2.7 & 2,8 & 2,2 & 2,8 & 1,7 & 1,9 & 1,4 \\
\hline & GDM-2.8 & 2,6 & 2,3 & 2,5 & 1,6 & 1,7 & 1,5 \\
\hline & GDM-2.9 & 3,4 & 2,3 & 3,5 & 2,6 & 2,8 & 1,6 \\
\hline & GDM-2.10 & 4,0 & 1,1 & 4,0 & 2,8 & 3,0 & 0,8 \\
\hline & GDM-2.11 & 3,0 & 1,5 & 2,9 & 1,3 & 1,5 & 1,2 \\
\hline & GDM-2.12 & 3,1 & 2,9 & 3,1 & 2,7 & 2,4 & 1,3 \\
\hline & GDM-2.13 & 3,3 & 1,8 & 3,2 & 1,6 & 2,0 & 1,1 \\
\hline & GDM-2.14 & 3,6 & 1,3 & 3,6 & 2,3 & 2,6 & 1,0 \\
\hline & GDM-2.15 & 2,4 & 2,5 & 2,1 & 1,2 & 1,3 & 2,6 \\
\hline & GDM-2.16 & 3,7 & 2,7 & 3,7 & 3,2 & 3,5 & 2,6 \\
\hline & GDM-2.17 & 3,4 & 1,7 & 3,3 & 1,5 & 1,8 & 1,0 \\
\hline GDM-3 & GDM-3.1 & 3,2 & 2,0 & 3,1 & 2,0 & 2,4 & 1,8 \\
\hline Community (non- & GDM-3.2 & 3,9 & 1,1 & 3,8 & 2,4 & 2,8 & 0,8 \\
\hline governmental & GDM-3.3 & 2,4 & 2,8 & 2,2 & 1,1 & 1,4 & 1,7 \\
\hline organizations) & GDM-3.4 & 3,5 & 1,3 & 3,3 & 1,6 & 2,0 & 1,1 \\
\hline Average & & 3,2 & 1,9 & 3,1 & 1,9 & 2,1 & 1,4 \\
\hline
\end{tabular}

Table 5: Ranking of regions to be built in order of priority

\begin{tabular}{lll}
\hline Kabupaten/Kota & Rata-rata & Rangking \\
\hline Kab. Pandeglang & 3,2 & 1 \\
Kab. Lebak & 3,1 & 2 \\
Kota Serang & 2,1 & 3 \\
Kota Cilegon & 1,9 & 4 \\
Kab. Tangerang & 1,9 & 5 \\
Kota Tangerang & 1,4 & 6 \\
\hline
\end{tabular}

After the item-rating value and similarity groups are obtained, the next step is to calculate the total similarity of both. Calculation of total similarity is done by Equation (4). In this study, the coefficient value of $\mathrm{c}$ is set at 0,4 . Based on the results of the trials conducted on the range of the coefficient value $c$, the closer to 1 , the predictive value of the item will be smaller; on the contrary the total similarity value will be even greater. Total similarity is used to calculate the predicted value of an item (region). Item prediction (region) then calculated the average and then sorted by the highest value. Prediction of items with the highest average is used as the final decision which region is prioritized for future 
development activities. Table 4 and 5 shows the results of the prediction of items and ranking regions which are the development priorities in the future.

Based on the final ranking results, there are three real regions that must be prioritized in the future by the government. The three regions are Kabupaten Pandeglang, Kabupaten Lebak and Kota Serang. Based on the results of the analysis of development data sourced from the Statistics Center, both using the Klassen and Location Quotient typologies indeed, the three regions are relatively lagging regions among other districts. The results of the analysis with the Klassen typology show that Kabupaten Pandeglang and Lebak belong to the category of advanced but depressed regions. While the other four regions belong to the category of developed regions and grow rapidly. Especially for Kota Serang, the results of the model developed show that this region is included in one of the areas that must be prioritized for future development. While the results of Klassen's analysis show that this region is actually a developed area and is growing rapidly. This is not surprising, because Kota Serang is a new area resulting from the expansion of Serang Regency. In statistical data of Kota Serang does have a growth rate of development that is not far from Kabupaten Pandeglang and Lebak. Therefore it is very reasonable if the output of the GDSS model is developed to classify the City of Serang into the next development priority area.

\section{Conclusion}

The GDSS model developed is an effort to provide new alternatives in determining development priorities in the future. This model is able to accommodate subjective judgments of decision makers combined with the results of data analysis using cluster and ICHM techniques. Therefore, prioritizing the area does not only prioritize subjective desires from policy makers. Among the six districts that are the sample of this study, there are three regions recommended for prioritizing future development activities, namely Kabupaten Pandeglang, Lebak and Kota Serang. Further research can combine the concept of multi-collinearity into the assessment analysis stage by experts who are members of the GDSS model. Thus the final assessment related to the priority of the region was built to pay attention to the relationship between expert experts.

\section{Author's Contributions}

Sri Setiyowati: Collecting data, analysis the data, develop the model of GDSS, analysis the data using ICHM.

Sumiati, Sutarti, Andrianto Heri Wibowo and Vidila Rosalina: Collecting data, distribute and analysis online questionnaire using basic statistical model.
Tb. Ai Munandar: Improve the result of data analysis, analysis the data using ICHM, corresponding author for publication needed.

\section{Ethics}

No ethical issues would arise after the publication of this manuscript.

\section{References}

Bakaric, I.R., 2005. Uncovering regional disparities - the use of factor and cluster analysis. Economic Trends Economic Policy.

Capuano, N., F. Chiclana, H. Fujita, E. Herrera-Viedma and V. Loia, 2018. Fuzzy group decision making with incomplete information guided by social influence. IEEE Trans. Fuzzy Syst., 26: 1704-1718. DOI: 10.1109/TFUZZ.2017.2744605

Chen, Y., X. Zhao, E. Rich and L.F. Luna-Reyes, 2018. Decision models and group decision support systems for emergency management and city resilience. Int. J. E-Plann. Res., 7: 35-50. DOI: 10.4018/IJEPR.2018040103

Djamal, R.A., W. Maharani and A.P. Kurniati, 2010. Analisis dan implementasi metode item-based clustering hybrid Pada recommender system. Proceeding of the Konferensi Nasional Sistem dan Informatika, (NSI' 10), Bahasa, pp: 216-222.

Endaryanto, T., M. Firdaus, H. Siregar and D.B. Hakim, 2015. The impact of regional expansion on economic structure: A case study in Lampung province, Indonesia. Int. J. Sci.: Basic Applied Res., 23: 1-18.

Fattah, S. and A. Rahman, 2013. Analysis of regional economic development in the regency/municipality at South Sulawesi province in Indonesia. J. Econom. Sustainable Dev., 4: 1-10.

Hariyanti, D. and M.A. Utha, 2016. Analysis of determinants sectors regional development at 33 provinces in Indonesia. Int. J. Sustainable Dev., 09: 11-32.

Instudor, I. and L. Duta, 2010. Web-based group decision support system: An economic application. Inform. Economică, 14: 191-200.

Karsinah, P.I. Putri, K.N. Rahayu and A.F. Panjiputri, 2016. The profile of pekalongan as a center of economic growth at tangkallangka strategic areas. Int. J. Econom. Financial Issues, 6: 105-109.

Laksana, E.A., 2014. Collaborative filtering dan aplikasinya. J. Ilmiah Teknol. Inform. Terapan., 1: 36-40.

Lan, J., Q. Sun, Q. Chen and Z. Wang, 2013. Group decision making based on induced uncertain linguistic OWA operators. Dec. Support Syst., 55: 296-303. DOI: 10.1016/j.dss.2013.01.030 
Lee, H.K. and H. Zo, 2016. Assimilation of military group decision support systems in Korea: The mediating role of structural appropriation. Inform. Dev., 33: 14-28. DOI: 10.1177/0266666916628316

Li, Q. and B.M. Kim, 2003. Clustering approach for hybrid recommender system. Proceedings of the IEEE/WIC International Conference on Web Intelligence, Oct. 13-17, IEEE Xplore Press, Halifax, NS, Canada, pp: 33-38. DOI: $10.1109 /$ WI.2003.1241167

Morente-Molinera, J.A., G. Kou, I.J. Pérez, K. Samuylov and A. Selamat et al., 2018. A group decision making support system for the Web: How to work in environments with a high number of participants and alternatives. Applied Soft Comput. J., 68: 191-201. DOI: 10.1016/j.asoc.2018.03.047

Munandar, T.A., Azhari, A. Mushdholifah and L. Arsyad, 2016. Hierarchical regional disparities and potential sector identification using modified agglomerative clustering. Proceedings of 1st Annual Applied Science and Engineering Conference, (SEC' 16).

Nikas, A., H. Doukas and L. Martínez López, 2018. A group decision making tool for assessing climate policy risks against multiple criteria. Heliyon, 4: e00588-e00588.

DOI: 10.1016/j.heliyon.2018.e00588
Rigopoulos, G., 2015. A group decision support system for collaborative decisions within business intelligence context. Am. J. Inform. Sci. Comput. Eng., 1: 84-93.

Silva Filho, J.L.E. and D.C. Morais, 2018. Group decision model based on ordered weighted distance to aid decisions on logistics. Int. J. Uncertainty Fuzziness Knowlege-Based Syst., 26: 233-254. DOI: $10.1142 / \mathrm{S} 0218488518500125$

Sinaga, D., 2015. Determination analysis of leading economic sector against forming region GDP in simalungun. Int. J. Innovative Res. Manage.

Suwandi, N., 2015. Economic inequality among districts in Keerom, Papua, Indonesia. J. Soc. Dev. Sci., 6: 30-34.

Zhao, X., Y. Chen, M. Ku, E. Rich and M. Deegan et al., 2017. Group decision support systems for emergency management and resilience: Coastal protect SIM. Proceedings of the 50th Hawaii International Conference on System Sciences, (CSS’ 17), pp: 2489-2497. 